\title{
WORKING CONDITIONS OF ACADEMIC PERSONNEL OF HIGHER EDUCATION INSTITUTIONS IN LATVIA
}

\author{
Dita Stefenhagena ${ }^{1}$, Dr.sc.admin.; Inga Vanaga ${ }^{2}$, Mg.sc.soc.; Anda Grinfelde ${ }^{3}$, Dr.oec. \\ 1,2,3 Latvian Trade Union of Education and Science Employees (LIZDA)
}

\begin{abstract}
Academic society is exposed to continuous growing demands and requirements - innovative pedagogical work, international recognition in research, cooperation with industry - these are just part of requirements which have to be ensured by academic staff at each higher education institution (HEI) in Latvia. The question arises - do working conditions of academic staff, taking into consideration described demands, duties and requirements, correspond with decent work practice, such as competitive pay and working stability? The aim of the research paper is to investigate if the factors influencing work of academic staff are following decent work practice. In order to reach the aim of the research paper, the authors have used the results of the Latvian Trade Union of Education and Science Employees (LIZDA) survey conducted at public higher education institutions in Latvia. The time period of survey was April - September, 2019. The target group of the survey were representatives of academic staff. The major conclusions of the research are the following: (1.) salary of academic staff isn't competitive with other public professions and positions in Latvia; (2.) working stability of academic staff is low because of insecure and precarious contracts; (3.) working conditions of academic personnel regarding competitive salary and work stability don't correspond with the decent work practice.
\end{abstract}

Key words: academic staff, working conditions, precarious contracts, uncompetitive salary, decent work. JEL code: I23

\section{Introduction}

The paper shows part of the research "For decent work of academic personnel in higher education institutions in Latvia", which was carried in 2019. The topicality of the research can be characterized as the following: academic staff is exposed to numerous duties and requirements which are regulated by the Higher Education Institutions' Law and the Law on Scientific Activities, as well by other normative regulations at national and institutional level. At the same time working conditions of the academic personnel may not correspond with decent work practice because of uncompetitive salary and precarious, unstable contracts. The prestige of academic positions is getting lower, and in many cases young people aren't interested in academic career.

The aim of the research is to investigate if the factors influencing work of academic staff are following decent work practice. The basic factors of decent work defined by international practice are the following:

- labour rights, working stability, competitive remuneration;

- social protection and environment - status, prestige, equality;

- possibilities for professional improvement and learning, self - assurance and career development;

- safe and health friendly working conditions and environment (International Labour Organization, 2019).

The United Nations Economic and Social Council has defined the "decent work" concept: decent work is employment that respects the fundamental rights of the human person as well as the rights of workers in terms of conditions of work safety and remuneration. ... respect for the physical and mental integrity of the worker in the exercise of his/her employment (United Nations, 2017). Thus, respect for decent work conditions include remuneration, safety and security. The following

\footnotetext{
${ }^{1}$ Dita Stefenhagena, LIZDA

2 Inga Vanaga, LIZDA

${ }^{3}$ Anda Grinfelde, LIZDA
} 
description of decent work aspects on the part of International Labour Organization also emphasizes fair income, security, personal

development. Decent work is applied to both the formal and informal sector. It must address all kind of jobs and people. Decent work is a multidimensional concept because it touches the humane grounds. According to the International Labour Organization, decent work involves opportunities for work that are productive and deliver a fair income, security in the workplace, better prospects for personal development and social integration, freedom for people to express their concerns, organize and participate in the decisions that affect their lives (ILO, 2017).

In order to reach the aim, the following tasks were set: (1.) research theoretical aspects of decent work criteria and practice using sources of normative regulations and reports of international labour organizations; (2.) use empirical results, concerning academic staff's opinion about their income, workload and contracts, from the research conducted by LIZDA in 2019; (3.) summarize the theoretical and empirical findings, organize a discussion and make conclusions.

Considering the limitations of the paper, the aspects of remuneration, contracts and workload of academic staff are those factors which have been analysed in the paper. This paper includes results and discussion about one thematic block - "Stability and security of academic staff's contracts, components of workload, remuneration." In total, there were five thematic blocks analysed in the research: (1.) higher education's policy impact on work of academic staff; (2.) stability and security of academic personnel's contracts, components of workload, remuneration; (3.) availability of professional improvement and career development; (4.) safe and study process friendly working environment;(5.) future challenges in working with students.

Research object: working conditions of academic personnel of public HEIs. Research subject: conformity of remuneration, workload and contracts with decent work practice. Authors used normative regulations and reports of international labour organizations as a theoretical basis, and the results of a survey for academic staff in public HEIs conducted in 2019, as an empirical basis.

Research question: do working conditions of academic staff, taking into consideration described demands, duties and requirements, correspond with decent work practice, i.e., competitive pay and working stability? Research based arguments help LIZDA to more efficiently represent interests of academic staff in social dialogue with education policy makers and HEIs' administration, and to achieve improved working conditions and environment for academic staff.

\section{Research results and discussion}

\section{Research methodology}

There are 28 public higher education institutions (including colleges) in Latvia (Higher Education Institutions in Latvia, IZM, 2019). The target group of the survey - academic staff in public higher education institutions. The total number of respondents (sample) -451 , which compile $4,5 \%$ of the general set of the academic staff $(\mathrm{N})$, and that is valid for the representation of the sample. The total number of elected and non-elected teachers of higher education institutions is approximately 10000 (5109 are elected and the rest - non-elected) (Ministry of Education and Science, 2019).

There are 105 questions (structured as statements) and 14 questions of respondents' demographic data included in the survey. There are 2 types of rating scales: (1.) Likert scale: 1 to 5, where 1-agree, 2-partly agree, 3-partly disagree, 4-disagree, 5-don't have opinion; (2.) rating scale from 1 to 3, where 1-yes, 2-no, 3- don't have opinion. Sample description indicates: from the total number of respondents $-451,74 \%$ are females, and $26 \%$ are males; $56 \%$ respondents work 
in more than one workplace; $36 \%$ respondents work in another education institution, incl. another HEI, and $64 \%$ are working in different institutions which aren't educational entities. The majority of respondents $(74 \%)$ are elected academic staff members, $32 \%$ work in professor or associated professor's positions, $58 \%$ - in docent, lecturer, assistant positions; $58 \%$ of respondents have obtained doctor's degree (PhD). Majority of respondents (64 \%) in academic position work part time; $40 \%$ respondents have 20 years of academic experience, and only $13 \%$ of respondents have academic experience less than 5 years. The majority of respondents ( $52 \%$ ) represent social, human and art sciences (52\%), the rest - natural sciences, engineering, technologies, medicine, health, agriculture, are represented less; $47 \%$ respondents obtain researcher's position along with the academic position; $75 \%$ of respondents are representatives from universities, $18 \%$ representatives from other HEIs incl. academies, $7 \%$ - representatives from colleges. All regions of Latvia (Riga, Zemgale, Kurzeme, Latgale, Vidzeme) were represented, but there wasn't equal number representation from the regions. That is connected with the fact that the majority of public HEIs are located in Riga; 59 \% from respondents are not LIZDA members, $14 \%$ from this percentage are members of other trade unions.

\section{Remuneration as one of the most important aspects in decent work practice}

The minimal rate for academic positions (assistant, lecturer, docent, assoc. professor, professor) is regulated by the Cabinet of Ministers regulations (MK regulations Nr.445, Pedagogu darba samaksas noteikumi.05.07.2016). On 15 January 2018 the government approved the salary increase schedule not only for teachers of general education but also for teaching personnel at the HEIs. The schedule indicated that each year for each academic position there should be $10 \%$ salary increase based on minimal rate of 2016 . Three years in a row $(2017,2018,2019)$ the salary increase was ensured and supported financially by the government, but in 2020 the state budget didn't find financial resources to support academic staff. Of course, some of HEIs are able to financially support their staff on a regular basis because of their own revenues, e.g. Riga Stradins University - because of large number of costly study programs and international students. Considering the fact that there are only some public HEIs which are able to support their academic staff using their own financial resources, there is large number of specialists representing academic positions whose salary isn't competitive. That can be proved by the fact that according to the Central Statistics Bureau information, the average public sector salary for a full workload was 1076 euro (pre-tax remuneration) in 2019 (CSB, 2018) but the minimal rate for the assistant professor's (docent) position - only 980 euro (pre-tax remuneration) (MK regulations Nr. 445, Pedagogu darba samaksas noteikumi.05.07.2016). Situation is reflected by the opinion represented by $96 \%$ respondents (answers 1-agree, 2-partly agree) who agree/partly agree with the statement that remuneration of academic personnel is generally low, and it doesn't correspond with decent work practice (Fig. 1). 


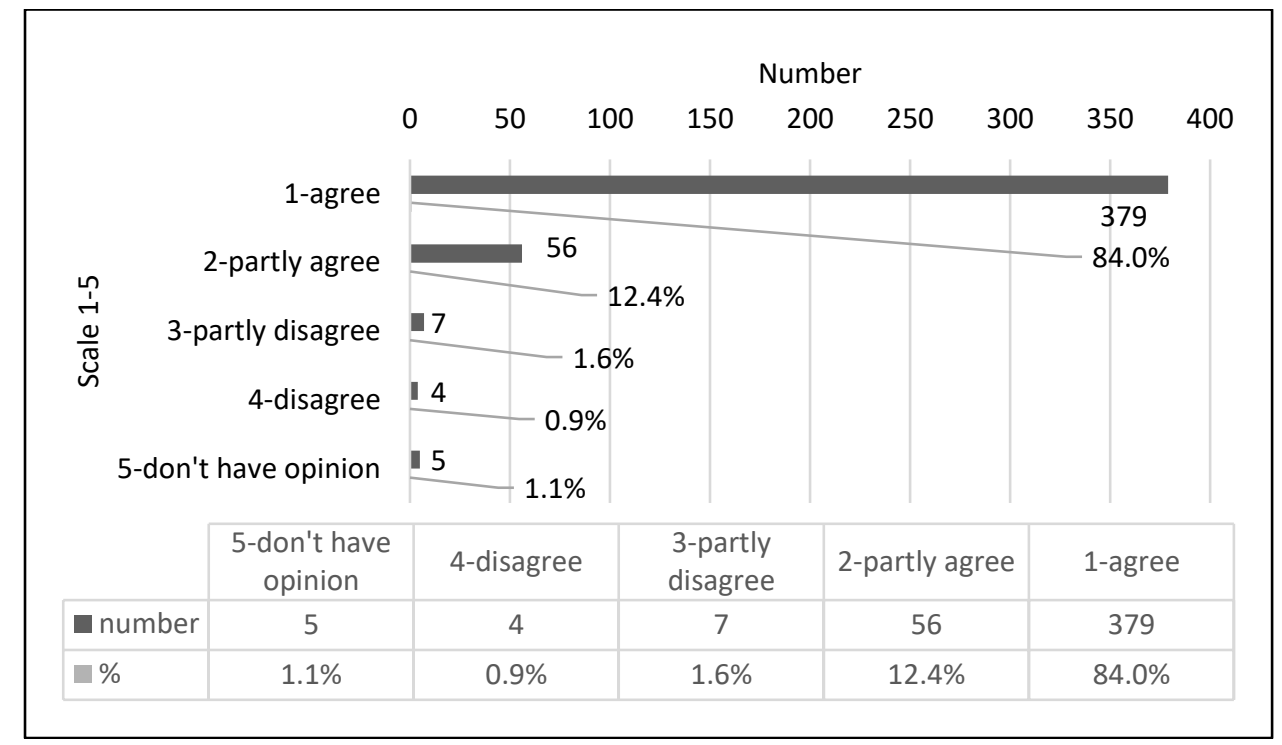

Fig. Respondents' opinion (\%, number) on statement "Remuneration of academic personnel of HEIs in Latvia is generally low, and it doesn't correspond with decent work conditions", $n=451$

Decreasing prestige of academic positions in the society follows the uncompetitive salary of academic personnel. Education sector in Latvia is in high demand for general education teachers, and there are positions available for lower level academic positions, e.g. assistants, lecturers, especially concerning STEM (science, technology, engineering, mathematics) programs. The survey indicated that $90 \%$ of respondents (answers: 1- agree, 2- partly agree) agree/partly agree with the statement that uncompetitive remuneration of academic personnel is one of the factors of decreasing prestige of academic positions in the society (Fig. 2).

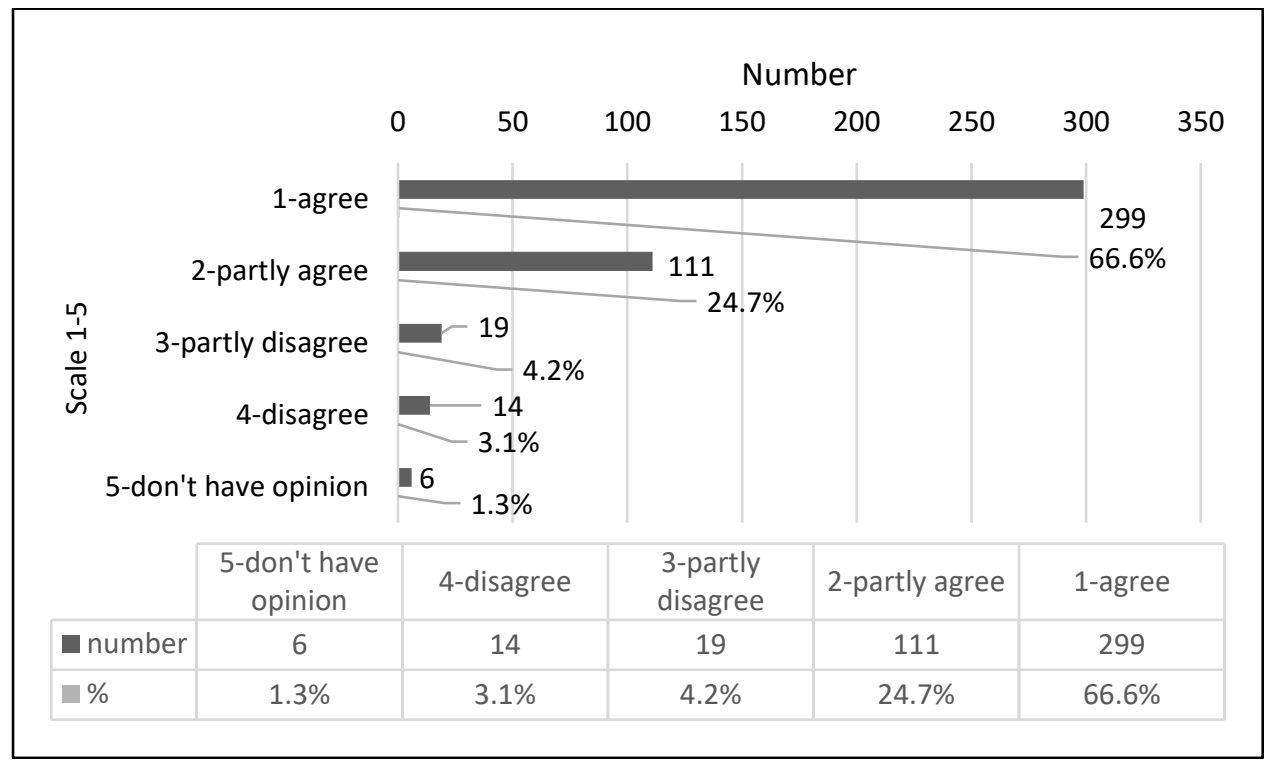

Fig. 2. Respondents' opinion (\%, number) on statement "Uncompetitive remuneration of academic personnel of HEIs is one of the major reasons of decreasing prestige of academic positions in the society", $n=451$

This situation may lead to decreasing prestige not only of academic positions, but also of academic education and science of Latvia in general. Higher education area is united in all EU, and Latvian HEIs are interested to increase their study and science quality and positive public image not only locally but internationally, too. 


\section{Different components of workload influence remuneration of academic staff and creates inequality}

The next aspect which was analysed is the workload of academic staff. The sample description indicated that $56 \%$ of respondents work in more than one workplace, and $64 \%$ of respondents work part time. $56 \%$ of respondents were of opinion that different work duties are included and paid for the same academic position and workload at HEI (Fig. 3).

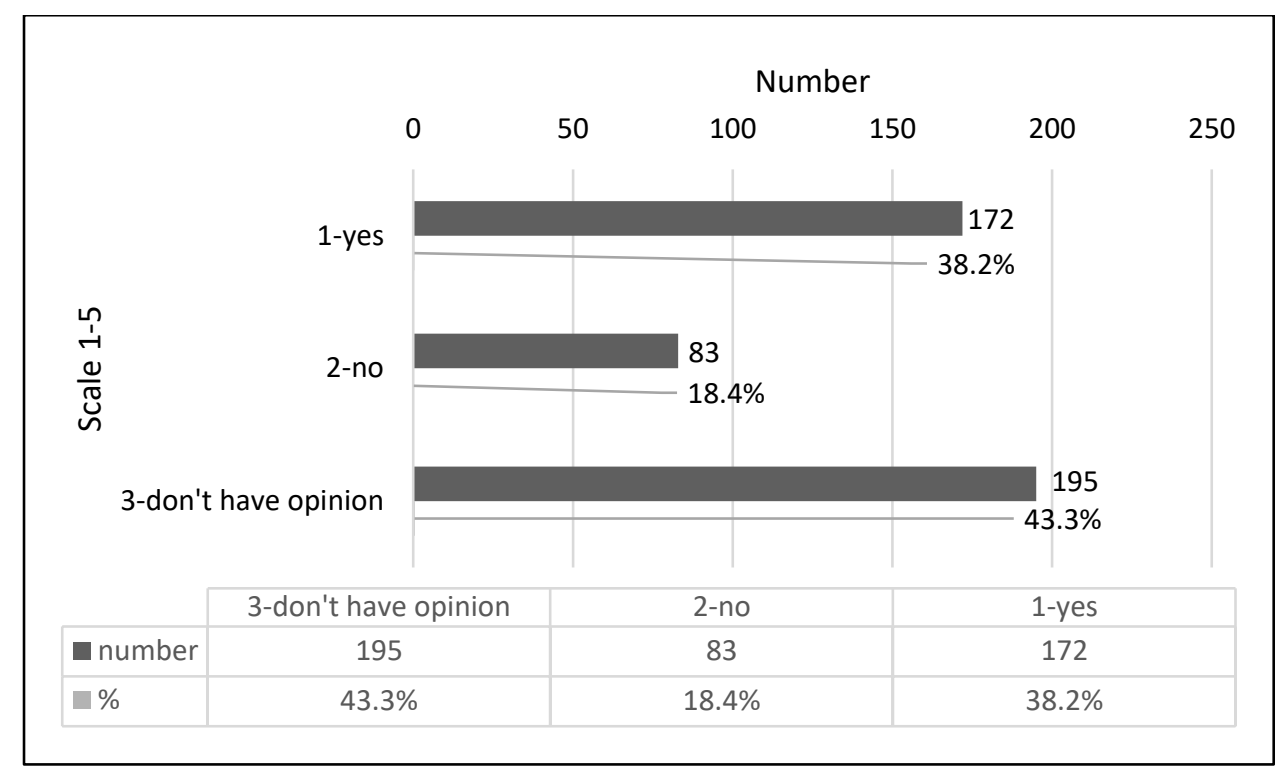

Fig. 3. Respondents' opinion (\%, number) on statement "Different work duties are included and paid for the same academic position and workload", $n=451$

That may raise an assumption that calculation of workload duties and salary isn't transparent. That is ensured by the fact that large percentage ( $43 \%)$, almost half of respondents didn't have opinion on this issue - they were not informed/didn't have information on how the workload is calculated, what are those components which are included and paid in the workload. Also, if the same position with the same workload has different salary, that may lead to an assumption of work inequality issue.

Starting from 2017, LIZDA repeatedly insisted that the Ministry of Education and Science (IZM) has to establish working group to assess the best practice of academic staff's workload calculations. This issue raised an interest also on the part of HEIs in Latvia (University of Latvia, Riga Stradins University, Riga Technical University, Latvia University of Life Sciences and Technologies and some others have expressed an interest) (LIZDA internal documentation, 2019).

The following table indicates respondents' opinion - what are those components which are included/aren't included in the workload calculations most frequently. 


\section{Components of academic staff's workload}

\begin{tabular}{|c|c|c|c|}
\hline No & Components & $\begin{array}{c}\text { Included in } \\
\text { workload } \\
\text { and paid }\end{array}$ & $\begin{array}{l}\text { Isn't included } \\
\text { and paid in } \\
\text { workload }\end{array}$ \\
\hline 1. & Scientific activities - publications, participation at conferences etc. & $(23 \%)$ & $(65 \%)$ \\
\hline 2. & Organizational duties at HEI & $(24 \%)$ & $(64 \%)$ \\
\hline 3. & Review of scientific papers & $(6 \%)$ & $(66 \%)$ \\
\hline 4. & $\begin{array}{l}\text { Participation at quality assurance procedures at program, } \\
\text { structural unit and HEI level }\end{array}$ & $(10 \%)$ & $(63 \%)$ \\
\hline 5. & Consultations for students & $(70 \%)$ & $(25 \%)$ \\
\hline 6. & Review of students' papers (essays, tests, reports etc.) & $(63 \%)$ & $(31 \%)$ \\
\hline 7. & Renewal of study courses' content & $(27 \%)$ & $(65 \%)$ \\
\hline 8. & $\begin{array}{l}\text { Development of e-study courses in Moodle or other electronic } \\
\text { platforms }\end{array}$ & $(17 \%)$ & $(67 \%)$ \\
\hline 9. & Lecturing in e-studies & $(14 \%)$ & $(57 \%)$ \\
\hline 10. & Leading bachelor and master theses & $(80 \%)$ & $(11 \%)$ \\
\hline 11. & $\begin{array}{l}\text { Methodological work - development of lectures, practical } \\
\text { seminars, etc. }\end{array}$ & $(30 \%)$ & $(63 \%)$ \\
\hline 12. & Lectures for international students & $(33 \%)$ & $(33 \%)$ \\
\hline
\end{tabular}

Source: Authors' research "For decent work of higher education institutions academic personnel in Latvia", 2019

The following components are frequently not included and paid in workload: scientific activities $(65 \%)$, including review of other authors" scientific papers, organizational duties at HEI $(64 \%)$, renewal of study courses content $(65 \%)$, development of e-study courses in Moodle or other electronic platforms (67\%), lecturing in e-studies (57\%). Quite a large percentage (33\%) of respondents point out that their work with international students isn't included and paid at the workload. Positively, that consultations for students (70\%), review of students' papers $(63 \%)$, supervising of bachelor and master theses ( $80 \%)$ are usually included in the workload of academic staff. The survey results show that there are numerous duties to be represented by the academic staff, concerning work with students, scientific and organizational work etc. At the same time, there is a risk, that part of these duties may not be included and paid in the workload of any academic position. The situation is complicated also by the fact the majority of academic staff is working part time workload, and it may not be clear how many of the responsibilities corresponding the respective workload have to be implemented by academic staff.

\section{Academic staff's contracts - correspondence with decent work practice}

As mentioned before, it is characteristic that academic staff in Latvia works part time. Eurydice has shown that countries like Latvia ( $80 \%$ ), Lithuania (60\%) and Estonia (40\%) are those with the highest specific rate of academic personnel who works part time in academic positions. At the same time, e.g. only $5 \%$ of academic personnel works part time in Poland (Eurydice, 2017). If a person in an academic position works in two or more institutions, that may cause "burn out" syndrome on the one hand, and on the other hand, there is a risk that academic quality may decrease. The data of the LIZDA survey indicates that frequent performance assessment of academic staff on the part of students, employers, external accreditors etc. creates additional tension, and the majority of academic personnel ( $82 \%$ ) point out that because of intensive workload they have experienced "burnout syndrome". 
Not only part time work, but also employment contract stability may influence work security of academic personnel. There are definite (fixed term) and indefinite contracts of academic personnel in Europe. Possibility to have indefinite contract exists in the majority of EU countries. Eurydice has stated that only in such countries as Slovakia and Latvia there doesn't exist indefinite contracts for academic staff (Eurydice, 2017). Academic personnel in all positions is elected for the time period of six years, and after this period new elections (public announcement for the position) are organized. That means that any academic position, e.g. professor or assistant professor (docent) may lose the job after the election period. An appeal for inconsistency with the Republic of Latvia Constitution was submitted in 2019 at the Republic of Latvia Constitutional Court. According to the appeal, the court's decision was that the situation doesn't correspond with the constitutional right for each person to freely choose employment in accordance with one's skills and qualification (Republic of Latvia, Decision of Constitutional Court, 2019.). Amendments in the Law on Higher Education Institutions are prepared. Changes will include possibilities for indefinite contracts for associate professors and professors to have indefinite contracts if elected two times in a row and if their academic and scientific assessment is positive. If the contract is fixed for the election period, that still may include changes in workload and remuneration. The majority of respondents $(55 \%)$ indicate that while they are elected in academic position for the period of six years, they experience workload and remuneration amendments during the contract period (Fig.4). In majority of cases it is connected with decrease of number of students in HEIS.

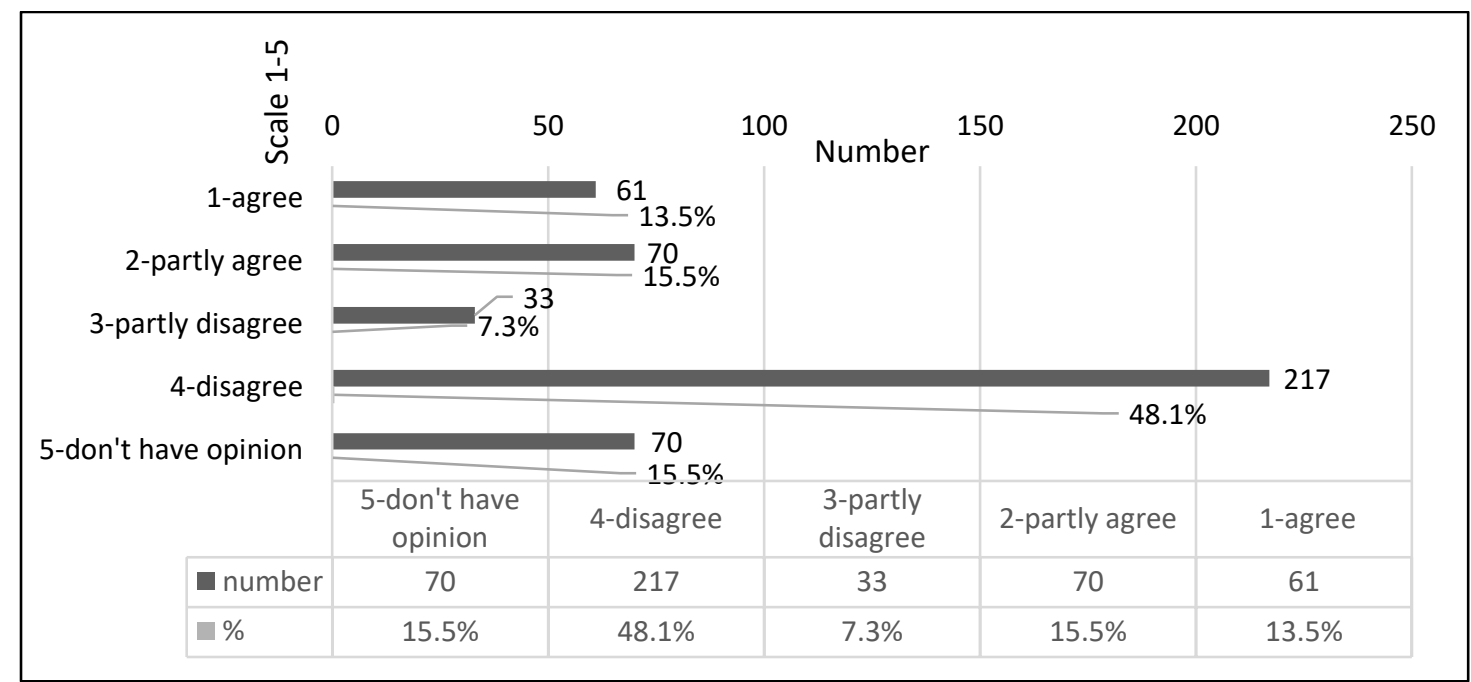

Fig. 4. Respondents' opinion (\%, number) on statement "Employment agreement is signed for six years, and workload and remuneration amendments aren't performed", $n=451$

Even worse situation is with that staff which isn't elected (and not included into the statistics of academic personnel) and works on a semester of study year basis. $50 \%$ of respondents (disagree, partly disagree) indicate that when the employment contract is concluded for one year, workload and remuneration are subjects for amendments during the contract period. Although there isn't seen a clearly expressed tendency, $46 \%$ of respondents indicate that they aren't informed about their study year contracts, including workload and remuneration, on a timely basis (at least one month before the beginning of the study year). 


\section{Conclusions and recommendations}

1) In comparison with other public sector professions, remuneration of academic personnel isn't competitive. Contracts of academic staff are insecure and precarious. At the same time both at everyday work and during the re-election process, academic staff is exposed to high, diversified requirements, including scientific and organizational work.

2) There aren't indefinite contracts for the academic staff. All contracts are fixed, concluded for a semester, one year, or six years. There should be a possibility for indefinite contracts in case an academic staff member is re-elected at the academic position several times in a row. Contract stability and security would be ensured at the level of each HEI management in case there is a sufficient state financing for higher education and science provided on the part of state budget.

3) Increased higher education and science state funding has to be provided in accordance with the normative regulations which are stipulated by the Higher Education Institutions' Law and the Law on Scientific Activities. Increased public funding would partly solve the problem of uncompetitive remuneration of academic staff.

\section{Bibliography}

1. Central Statistical Bureau (CSB). Available at: https://www.csb.gov.lv/lv/statistika/statistikas-temas/socialieprocesi/darba-samaksa/meklet-tema. Reviewed: 01.03.2020.

2. Factors of decent work. International Labour Organization. Reviewed: 02.02.2020. Available at: https://www.ilo.org/global/research/lang--en/index.htm

3. Higher Education Institutions in Latvia in 2019. Ministry of Education and Science (IZM). Reviewed: 02.02.2020. Available at: https://www.izm.gov.Iv/lv/izglitiba/augstaka-izglitiba/augstakas-izglitibas-iestades

4. LIZDA internal documentation (2019). Reviewed: 10.03.2020. Available at: https://www.lizda.Iv/aktualitates/jaunumi/

5. MK regulations Nr.445, Pedagogu darba samaksas noteikumi.05.07.2016. Reviewed: 02.02. 2010. Available at: https://likumi.Iv/ta/id/283667-pedagogu-darba-samaksas-noteikumi

6. Modernization of Higher Education in Europe: Academic Staff (2017). Eurydice publication. Reviewed: 10.03.2020. Available at: https://eacea.ec.europa.eu/national-policies/eurydice/content/modernisationhigher-education-europe-academic-staff-\%E2\%80\%93-2017_en

7. "Par augstakas izglitibas iestazu macibspeku darba apstakliem" rezultati un prezentacijas. Reviewed: 02.02.2020. Available at: https://www.lizda.Iv/projects_and_studies/aptaujas-par-augstakas-izglitibasiestazu-macibspeku-darba-apstakliem-rezultati/

8. Republic of Latvia, Decision of Constitutional Court, 2019. (LR Satversmes tiesas spriedums). "ParAugstskolulikuma27. pantapiektasdalasun30.pantaceturtasdalasatbilstibuLatvijasRepublikasSatversmes1 06.pantapirmajamteikumam" . Reviewed: 01.02. 2020. Available at: https://www.satv.tiesa.gov.lv/web/viewer.html?file=/wp-content/uploads/2018/08/2018-1501_Spriedums.pdf\#search=beztermi\%C5\%86a

9. United Nations Economic and Social Council: Promoting the MDGs: The Role of Employment and Decent Work (2017). United nations chronicle. Reviewed: 03.03.2020. Available at: https://www.un.org/en/chronicle/article/promoting-mdgs-role-employment-and-decent-work 